\title{
Effect of Surface Treatments on the Bond Strength of a Resin Cement to Commercially Pure Titanium
}

\author{
Antonio Alves de ALMEIDA-JÚNIOR \\ Renata Garcia FONSECA \\ Isabella Gagliardi HANEDA \\ Filipe de Oliveira ABI-RACHED \\ Gelson Luis ADABO
}

Department of Dental Materials and Prosthodontics, Araraquara Dental School, São Paulo State University, Araraquara, SP, Brazil

\begin{abstract}
Investigation of the effectiveness of surface treatments that promote a strong bond strength of resin cements to metals can contribute significantly to the longevity of metal-ceramic restorations. This study evaluated the effect of surface treatments on the shear bond strength (SBS) of a resin cement to commercially pure titanium (CP Ti). Ninety cast $\mathrm{CP}$ Ti discs were divided into 3 groups ( $\mathrm{n}=30$ ), which received one of the following airborne-particle abrasion conditions: (1) $50 \mu \mathrm{m} \mathrm{Al}{ }_{2} \mathrm{O}_{3}$ particles; (2) $30 \mu \mathrm{m}$ silica-modified $\mathrm{Al}_{2} \mathrm{O}_{3}$ particles (Cojet Sand); (3) $110 \mu \mathrm{m}$ silica-modified $\mathrm{Al}_{2} \mathrm{O}_{3}$ particles (Rocatec). For each airborne-particle abrasion condition, the following post-airborne-particle abrasion treatments were used ( $\mathrm{n}=10)$ : (1) none; (2) adhesive Adper Single Bond 2; (3) silane RelyX Ceramic Primer. RelyX ARC resin cement was bonded to CP Ti surfaces. All specimens were thermally cycled before being tested in shear mode. Failure mode was determined. The best association was Rocatec plus silane. All groups showed $100 \%$ adhesive failure. There were combinations that promote higher SBS than the protocol recommended by the manufacturer of RelyX ARC.
\end{abstract}

Key Words: resin cement, titanium, surface treatment, silica coating, airborne-particle abrasion.

\section{INTRODUCTION}

For cement metal restorations, resin cement seems to be a suitable option because it shows the best combination of physical and mechanical properties when compared to zinc phosphate and glass ionomer cements (1). Resin cements can be classified as adhesive or nonadhesive. The adhesive resin cements (e.g. Panavia F, Bistite II, C\&B Metabond and Super Bond C\&B), in addition to micromechanical retention, contain functional monomers that promote chemical bonding between the cement and the metal surface oxides (2). Whereas the non-adhesive resin cements (e.g. Enforce, Variolink II and RelyXARC) bond to the surface of metal restorations exclusively by means of micromechanical retention (3).

According to Tsuchimoto et al. (4), a strong and durable resin-based material bond to a substrate depends on both micromechanical retention and chemical bonding. In cementation with adhesive resin cements, this condition can be attained simply by airborne-particle abrasion with aluminum-oxide $\left(\mathrm{Al}_{2} \mathrm{O}_{3}\right)$ particles. In the case of the non-adhesive resin cements, both bonding mechanisms must be created.

For this purpose, metal surface treatments can be used, which are classified into: 1) promoters of micromechanical retention; 2) promoters of chemical bonding and 3) promoters of micromechanical retention and chemical bonding.

Among the promoters of micromechanical retention, airborne-particle abrasion with $\mathrm{Al}_{2} \mathrm{O}_{3}$ particles is most widely used $(5,6)$. This procedure cleans the surface and increases the surface area (7). Furthermore, it also decreases surface tension and creates a highly activated surface, favoring the wettability of the substrate by the material applied afterwards $(5,6,8)$. Other surface treatments such as roughening with a diamond bur (9) and chemical etching $(4,10)$ also fall into this category. Although adhesives have not been mentioned in the litera-

Correspondence: Profa. Dra. Renata Garcia Fonseca, Departamento de Materiais Odontológicos e Prótese, Faculdade de Odontologia de Araraquara, UNESP, Rua Humaitá, no 1680, $4^{\circ}$ andar, sala 411, 14801-903 Araraquara, São Paulo, Brasil. Tel: +55-16-3301-6426. Fax: +55-16-3301-6406. email: renata@foar.unesp.br 
ture as belonging to one of the three existent categories, because of their lower viscosity in comparison with the viscosity of resin cements, they could perhaps provide greater contact between the cement and substrate, thus favoring micromechanical retention.

Chemical bonding can be achieved with metal primers and silanes. Metal primers contain active monomers such as MDP, MEPS, 4-META and others that react chemically with the oxides present on the metal surface $(11,12)$. Silanes, due their bifunctional characteristics, establish a chemical bond between the resin matrix and the metal surface $(7,13)$.

Finally, a third category of surface treatment promotes both micromechanical retention and chemical bonding. One known method to achieve both bonding mechanisms is tribochemical silica coating. This method uses airborne-particle abrasion with silica-modified $\mathrm{Al}_{2} \mathrm{O}_{3}$ particles in conjunction with silanization (Cojet Sand and Rocatec; 3M ESPE, Seefeld, Germany) (8). Cojet Sand has a particle size of $30 \mu \mathrm{m}$, is applied in a single step and is indicated for chairside application with the use of a chairside air abrasion device. Rocatec has a particle size of $110 \mu \mathrm{m}$, requires pre-treatment by airborne-particle abrasion with $\mathrm{Al}_{2} \mathrm{O}_{3}$ particles and was developed for laboratory use. However, there is no reason to contra-indicate its use in the dental office.

Considering the importance of an effective bond at the metal/cement interface, as well as the diversity of surface treatments and their possible combinations, the purpose of this study was to evaluate the effect of different surface treatments on the bond strength of a non-adhesive resin cement to commercially pure titanium (CP Ti).

\section{MATERIAL AND METHODS}

Ninety CP Ti grade II (RMI Co, Niles, OH, USA) discs $(9.0 \mathrm{~mm}$ in diameter and $3.0 \mathrm{~mm}$ thick) were cast in the Discovered Plasma Ar-arc vacuum-pressure casting machine (EDG Equipamentos e Controles Ltd, São Carlos, SP, Brazil) and embedded in a polyvinyl chloride (PVC) tube (20.0 $\mathrm{mm}$ in diameter and $27.0 \mathrm{~mm}$ high), using polymethyl methacrylate acrylic resin (ClasMold; Artigos Odontológicos Clássico Ltd, São Paulo, SP, Brazil). The bonded surfaces of all specimens were smoothed with 150, 400 and 600-grit silicon carbide papers (3M Brazil Ltd, Campinas, SP, Brazil) using a polisher (Metaserv 2000; Buehler UK Ltd, Coventry, England).
The specimens were divided into 3 groups $(n=30)$, which were subjected to one of the following airborneparticle abrasion conditions: 1) $50 \mu \mathrm{m}$ aluminum-oxide $\left(\mathrm{Al}_{2} \mathrm{O}_{3}\right)$ particles (Bio-Art Equip. Odontol. Ltd., São Carlos, SP, Brazil); 2) $30 \mu \mathrm{m}$ silica-modified $\mathrm{Al}_{2} \mathrm{O}_{3}$ particles (Cojet Sand; 3M ESPE, Germany); 3) $110 \mu \mathrm{m}$ silica-modified $\mathrm{Al}_{2} \mathrm{O}_{3}$ particles (Rocatec; $3 \mathrm{M}$ ESPE, Germany). For each airborne-particle abrasion condition, the following post-airborne-particle abrasion treatments were used ( $n=10)$ : 1) none; 2 ) adhesive; 3) silane.

Airborne-particle abrasion was performed for 10 $\mathrm{s}$ with an airborne-particle abrasive unit (Basic Classic; Renfert $\mathrm{GmbH}$, Hilzingen, Germany), at 4,8 bar pressure, at a 90-degree angle and at a distance of $10.0 \mathrm{~mm}$ from the specimen surface. All specimens were ultrasonically cleaned in distilled water for $10 \mathrm{~min}$.

The adhesive Adper Single Bond 2 (3M ESPE, St. Paul, MN, USA) (LOT \#51202) was applied, according to manufacturer's directions, and light-cured for $20 \mathrm{~s}$ using a light-curing unit (Curing Light XL 3000; 3M ESPE, USA) at an irradiance of approximately $550 \mathrm{~mW} /$ $\mathrm{cm}^{2}$ and at a distance of $5.0 \mathrm{~mm}$ from the specimen surface. The silane coupling agent RelyX Ceramic Primer (3M ESPE, USA) (LOT \#2721) was applied to the alloy surface with a disposable brush and left to set for $60 \mathrm{~s}$.

For the application of the RelyX ARC resin cement (3M ESPE, USA) (LOT CKCK), a custom-made metal matrix $(5.0 \mathrm{~mm}$ internal diameter and $2.0 \mathrm{~mm}$ thick) was positioned on the surface of the specimen using a centralizing ring attached to the PVC tube. The cement was proportioned by weight. To avoid exposure to daylight (so that there would be chemical activation only), the resin cement was mixed in accordance with the manufacturer's instructions and inserted into the matrix inside a radiographic developing chamber (Odontologic Indústria e Comércio Ltd, São Paulo, SP, Brazil).

Forty minutes after preparation, all specimens were stored in distilled water at $37^{\circ} \mathrm{C}$ for $24 \mathrm{~h}$ before thermal cycling between $5^{\circ} \mathrm{C}$ and $55^{\circ} \mathrm{C}$ for 5,000 cycles with a 30 -s dwell time. Specimens were tested for shear bond strength (Fig. 1) using a testing machine (810 Material Test System; MTS Systems Corp, Eden Prairie, MN, USA), with a $1 \mathrm{kN}$ load cell. A knife-edge-shearing rod running at a crosshead speed of $0.5 \mathrm{~mm} / \mathrm{min}$ was used to load the specimens until fracture. Shear bond strength values were recorded in MPa.

Each specimen was examined under an optical microscope (M80; Leica Microsystems Ltd, Heerbrugg, Switzerland) at $20 \times$ magnification, and digital images 
were captured by a computer software (Leica Application Suite EZ; Leica Microsystems Ltd). Failure mode was recorded by a single calibrated observer as either adhesive (between metal and resin cement), cohesive (within the resin cement) or combination (areas of adhesive and cohesive failure). For this classification, the adhesive area was divided into quadrants, and in each of them, the predominant type of fracture was observed. According to the method of Santos et al. (14), the fracture was classified as adhesive or cohesive if either of these types predominated in 3 or more quadrants, and classified as combination if 2 quadrants presented adhesive failure and the other 2 cohesive failure.

Data were analyzed using a 2-way ANOVA followed by Tukey's multiple-comparison test at a level of significance of $\alpha=0.05$, with airborne-particle abrasion condition $\left(50 \mu \mathrm{m} \mathrm{Al}_{2} \mathrm{O}_{3}\right.$ particles; Cojet Sand; Rocatec) and post-airborne-particle abrasion treatment (none; adhesive; silane) as factors.

\section{RESULTS}

The results of the two-way ANOVA revealed that airborne-particle abrasion, post-airborne-particle abrasion and their interaction were significant $(p<0.001)$.

Table 1 shows the mean shear bond strength values and standard deviations for each group and statistical results. When the factor airborne-particle abrasion condition was investigated, there was no significant difference $(\mathrm{p}>0.05)$ between $50 \mu \mathrm{m} \mathrm{Al}_{2} \mathrm{O}_{3}$ particles and Rocatec, but both conditions showed higher bond strength than Cojet Sand $(\mathrm{p}<0.05)$. When the factor postairborne-particle abrasion treatment was investigated, there was significant difference among the 3 treatments

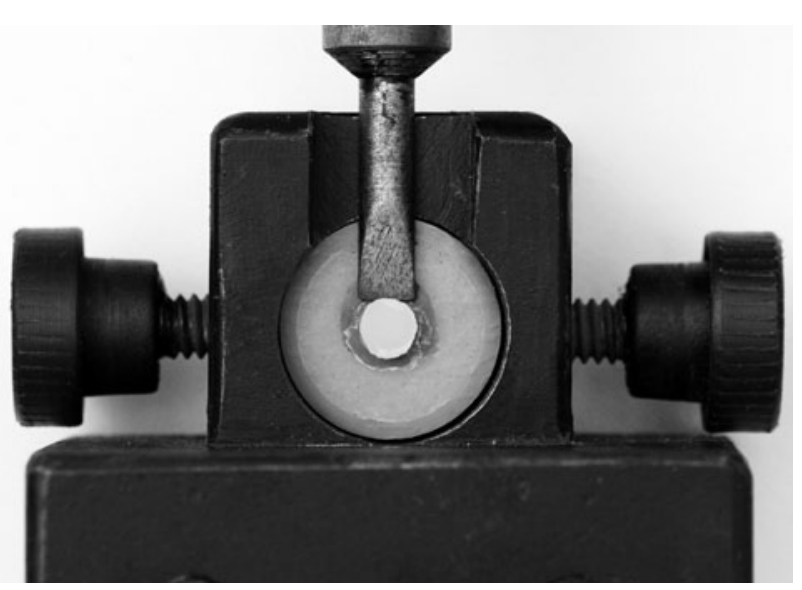

Figure 1. Shear bond strength testing apparatus.
( $<<0.001$ ), with silane having promoted the highest bond strength. The lowest bond strength was found when no post-airborne-particle abrasion treatment was used.

With regard to the significant interaction between airborne-particle abrasion condition and postairborne-particle abrasion treatment $(p<0.001)$, in the post-airborne-particle abrasion treatment with silane, in which there is chemical bonding, the airborne-particle abrasion with $50 \mu \mathrm{mAl}_{2} \mathrm{O}_{3}$ particles exhibited lower bond strength than Cojet Sand and Rocatec $(\mathrm{p}<0.05)$. When no post-airborne-particle abrasion treatment was used, there was no significant difference $(p>0.05)$ between Rocatec and Cojet Sand. In the groups abraded with $50 \mu \mathrm{m} \mathrm{Al}{ }_{2} \mathrm{O}_{3}$ particles, the adhesive was the best postairborne-particle abrasion treatment $(\mathrm{p}<0.001)$, there having been no significant difference $(p>0.05)$ between the group treated with silane and the group that did not receive post-airborne-particle abrasion treatment. In the airborne-particle abrasion with Cojet Sand, there was no significant difference $(\mathrm{p}>0.05)$ between the group treated with adhesive and the group that did not receive post-airborne-particle abrasion treatment.

Rocatec plus silane was the combination of airborne-particle abrasion condition and post-airborneparticle abrasion treatment that promoted the highest bond strength. No significant difference $(\mathrm{p}>0.05)$ was found between $50 \mu \mathrm{m} \mathrm{Al}_{2} \mathrm{O}_{3}$ particles plus adhesive and Cojet Sand plus silane $(\mathrm{p}>0.05)$. All groups showed $100 \%$ adhesive failure.

\section{DISCUSSION}

The guidelines for cementing with RelyX ARC

Table 1. Mean shear bond strength values (standard deviations) (MPa) and statistical results.

\begin{tabular}{lccc}
\hline $\begin{array}{l}\text { Post-airborne- } \\
\text { particle } \\
\text { abrasion } \\
\text { treatments }\end{array}$ & \multicolumn{3}{c}{ Airborne-particle abrasion conditions } \\
\cline { 2 - 4 } & $\begin{array}{c}50 \mu \mathrm{m} \\
\mathrm{Al}_{2} \mathrm{O}_{3}\end{array}$ & Cojet Sand & $\begin{array}{c}50 \mu \mathrm{m} \mathrm{Al}_{2} \mathrm{O}_{3} \\
+ \text { Rocatec }\end{array}$ \\
\hline None & 4.10 & 2.58 & 3.65 \\
& $(0.79) \mathrm{Ba}$ & $(0.37) \mathrm{Bb}$ & $\begin{array}{c}(0.70) \mathrm{Cab} \\
\text { Adhesive }\end{array}$ \\
& 6.14 & 2.31 & 5.25 \\
Silane & $(0.99) \mathrm{Aa}$ & $(0.23) \mathrm{Bb}$ & $(1.08) \mathrm{Ba}$ \\
& 4.34 & 5.70 & 8.36 \\
\hline
\end{tabular}

Different uppercase letters in columns and lowercase letters in rows indicate statistically significant differences $(p<0.05)$. 
resin cement recommend only the application of a silane coupling agent on the inner surface of previously $\mathrm{Al}_{2} \mathrm{O}_{3}$ airborne-particle abraded metal restorations. In the present study, the efficacy of alternative surface treatments was investigated, providing situations with micromechanical retention only and also with both bonding mechanisms.

In all the situations in which there was only micromechanical retention (no silane coupling agent), there was no significant difference between airborneparticle abrasion with $50 \mu \mathrm{mAl}_{2} \mathrm{O}_{3}$ particles and Rocatec. However, both conditions showed higher bond strength than Cojet Sand, except when no post-airborne-particle abrasion treatment was used; in this situation, there was statistical equality between Cojet Sand and Rocatec.

Although there were particles with different chemical compositions among the airborne-particle abrasion conditions used in this study, as there was a condition of $\mathrm{Al}_{2} \mathrm{O}_{3}$ particles only ( $50 \mu \mathrm{m}$ particles) and two of silica-modified $\mathrm{Al}_{2} \mathrm{O}_{3}$ particles (Cojet Sand and Rocatec), a possible explanation for the results obtained, would be the particle size.

Some studies (15-19) have shown evidence of the influence of particle size on the bond strength of resin-based materials to metals. Several authors (15-17) found significantly higher bond strength with smaller $\mathrm{Al}_{2} \mathrm{O}_{3}$ particles compared to larger sized $\mathrm{Al}_{2} \mathrm{O}_{3}$ particles. However, the influence of this factor on titanium was not evaluated in any of these three studies. Other studies $(18,19)$ have evaluated the bond strength of resin-based materials to CP Ti and have shown exactly the opposite; that is, larger $\mathrm{Al}_{2} \mathrm{O}_{3}$ particles promoted higher mean shear bond strength than the smaller particles. Papadopoulos et al. (18) observed that larger $\mathrm{Al}_{2} \mathrm{O}_{3}$ particles increase the roughness of the $\mathrm{CP}$ Ti surface, making it more favorable to micromechanical retention.

The statistical equality observed between the airborne-particle abrasion with $50 \mu \mathrm{m} \mathrm{Al}_{2} \mathrm{O}_{3}$ particles and with Rocatec could have been the result of previous airborne-particle abrasion, also with $50 \mu \mathrm{m} \mathrm{Al}_{2} \mathrm{O}_{3}$ particles, performed in Rocatec. Based on previous studies $(18,19)$, if this previous airborne-particle abrasion in Rocatec had been done with $110 \mu \mathrm{m} \mathrm{Al}_{2} \mathrm{O}_{3}$ particles; that is with particles of the same size as the silica-modified $\mathrm{Al}_{2} \mathrm{O}_{3}$ particles of Rocatec, it may be that this silica coating system may have been superior to the airborne-particle abrasion with $50 \mu \mathrm{m} \mathrm{Al}_{2} \mathrm{O}_{3}$ particles. This same line of reasoning could also be used to justify the superiority of the $50 \mu \mathrm{m} \mathrm{Al}_{2} \mathrm{O}_{3}$ particles and of Rocatec over Cojet Sand, which has a smaller sized particle $(30 \mu \mathrm{m})$.

On the other hand, in the situations in which there was both micromechanical retention and chemical bonding, both silica coating systems (Cojet Sand and Rocatec) exhibited significantly higher bond strength than the airborne-particle abrasion with $50 \mu \mathrm{m} \mathrm{Al}_{2} \mathrm{O}_{3}$ particles. Therefore, when the silane coupling agent was used, the chemical composition of the particles (silica-modified or not) was a more decisive factor in bond strength than the particle size. Nevertheless, Rocatec $(110 \mu \mathrm{m})$ promoted significantly higher mean shear bond strength than Cojet Sand $(30 \mu \mathrm{m})$, which is in agreement with the findings of previous investigations $(18,19)$.

As regards the superiority of silane compared to no post-airborne-particle abrasion treatment and adhesive, this behavior could be justified by the chemical bonding this material promotes, since it is an additional bonding mechanism, as the airborne-particle abrasion already promotes micromechanical retention. Silanes establish a chemical bond between the resin matrix and the metal surface due their bifunctional characteristics. The non-hydrolysable organic group contains carbon-carbon double bond which can polymerize with monomers of the resin-based materials. The hydrolysable groups react with an inorganic hydroxyl-rich (-OH) surface such as silica-coated $\left(\mathrm{SiO}_{2}\right)$ metal surfaces $(7,13)$. This justifies the superiority of silane in the groups abraded with Cojet Sand and Rocatec, observed in the present study.

On the other hand, in the groups airborne-particle abraded with $50 \mu \mathrm{m} \mathrm{Al}_{2} \mathrm{O}_{3}$ particles, the adhesive promoted significantly higher bond strength than the silane. Papadopoulos et al. (18) observed that when airborne-particle abrasion with $50 \mu \mathrm{m} \mathrm{Al}_{2} \mathrm{O}_{3}$ particles was performed, high alumina contamination of the $\mathrm{CP}$ Ti surface was detected. According to Matinlinna et al. (7), if alumina is embedded into a substrate, it provides hydrolytically unstable $=\mathrm{Al}-\mathrm{O}-\mathrm{Si} \equiv$ bonds which are weaker than $\equiv \mathrm{Si}-\mathrm{O}-\mathrm{Si} \equiv$ bonds.

This perhaps justifies the fact that in the groups abraded with $50 \mu \mathrm{mAl}_{2} \mathrm{O}_{3}$ particles, there was no statistical difference when silane or no post-airborne-particle abrasion treatments were used. Therefore, the RelyX ARC manufacturer's recommendations regarding the internal surface treatment of metal ceramic restorations could be reviewed. The superiority of the adhesive over no post-airborne-particle abrasion treatment can be possibly explained by the fact that this material favors better resin cement wettability on the metal surface than when 
the cement is applied directly on the airborne-particle abraded surface. In the groups abraded with Cojet Sand, the statistical equality observed between the adhesive and no post-airborne-particle abrasion treatment, could have occurred due to less surface roughness resulting from the airborne-particle abrasion with $30 \mu \mathrm{m}$ particles; that is, it does nothing to increase contact of the cement with a surface that is not very rough.

Finally, three combinations achieved significantly higher bond strength than the protocol recommended by the RelyX ARC manufacturer, as the four situations presented a predominance of adhesive failure. One of the combinations was the airborne-particle abrasion with Rocatec plus silane, which provided the highest bond strength. As pre-treatment, Rocatec requires airborne-particle abrasion with $110 \mu \mathrm{m} \mathrm{Al}_{2} \mathrm{O}_{3}$ particles. Although this pre-treatment was performed with $50 \mu \mathrm{m}$ $\mathrm{Al}_{2} \mathrm{O}_{3}$ particles in the present study, it still presented the highest bond strength. Further studies must be conducted to investigate the effect of different $\mathrm{Al}_{2} \mathrm{O}_{3}$ particle sizes used for pre-treatment as well as the effect of not performing this pre-treatment, on the bond strength of resin cements to metal surfaces abraded with Rocatec. Moreover, although this system having been developed for laboratory use, the inner surface of restorations can be airborne-particle abraded with Rocatec by using a chairside air abrasion device.

Ranked second, there is airborne-particle abrasion with $50 \mu \mathrm{mAl}_{2} \mathrm{O}_{3}$ particles plus adhesive (micromechanical retention only) and airborne-particle abrasion with Cojet Sand plus silane (both bonding mechanisms), which were statistically equal to each other. This statistical equality, as well as the superiority of $50 \mu \mathrm{m}$ $\mathrm{Al}_{2} \mathrm{O}_{3}$ particles plus adhesive when compared with the protocol recommended by the manufacturer of RelyX $\mathrm{ARC}$, indicate that certain combinations of treatments that favor micromechanical retention may be capable of producing bond strengths that are as strong as those resulting from treatments that promote both bonding mechanisms.

This study showed evidence of the superiority of some of the combinations to others, with decisive factors in determining the bond strength being the particle size under certain conditions and the chemical composition of the particles in others. Nevertheless, there are some factors that were not considered in the present study, which can influencing the bond strength of resin cement to CP Ti. Therefore, careful interpretation in the clinical application of the results is suggested. Studies that evaluate factors simulating the conditions of the oral cavity, such as long-term water storage, dynamic fatigue loading and $\mathrm{pH}$ changes should be carried out to affirm whether or not the evaluated combinations are effective (20).

Within the limitations of an in vitro study, the following conclusions were drawn: (1) with regard to the existence of exclusively micromechanical retention, the airborne-particle abrasion with $50 \mu \mathrm{mAl}_{2} \mathrm{O}_{3}$ particles and Rocatec promoted bond strengths that were equal to each other, and higher than those promoted by Cojet Sand; (2) in the post-airborne-particle abrasion treatment with silane, the airborne-particle abrasion with $50 \mu \mathrm{m} \mathrm{Al}_{2} \mathrm{O}_{3}$ particles exhibited the lowest bond strength and Rocatec, the highest SBS; (3) in general, Rocatec exhibited higher SBS than Cojet Sand; (4) silane was indispensable after airborne-particle abrasion with Rocatec and Cojet Sand; (5) three combinations presented higher SBS than that of the RelyX ARC manufacturer's protocol.

\section{RESUMO}

A investigação da eficácia de tratamentos de superfície que promovem uma forte resistência de união de cimentos resinosos aos metais pode contribuir significantemente para a longevidade das restaurações metalocerâmicas. Este estudo avaliou o efeito de tratamentos de superfície na resistência ao cisalhamento da união de um cimento resinoso ao titânio comercialmente puro (Ti $\mathrm{cp}$ ). Noventa discos foram fundidos em Ti cp e divididos em 3 grupos ( $\mathrm{n}=30)$, os quais receberam uma das seguintes condições de jateamento: (1) partículas de $\mathrm{Al}_{2} \mathrm{O}_{3}$ de $50 \mu \mathrm{m}$; (2) partículas de $\mathrm{Al}_{2} \mathrm{O}_{3}$ modificadas por sílica de $30 \mu \mathrm{m}$ (Cojet Sand); (3) partículas de $\mathrm{Al}_{2} \mathrm{O}_{3}$ modificadas por sílica de $110 \mu \mathrm{m}$ (Rocatec). Para cada condição de jateamento, os seguintes tratamentos pós-jateamento foram utilizados ( $\mathrm{n}=10)$ : (1) nenhum; (2) adesivo Adper Single Bond 2; (3) silano RelyX Ceramic Primer. O cimento resinoso RelyXARC foi aplicado à superfície do Ti cp. Todos os espécimes foram termociclados antes do ensaio de cisalhamento. O modo de fratura também foi determinado. A melhor associação foi o Rocatec mais silano. Todos os grupos apresentaram 100\% de falha adesiva. Houve combinações que promoveram maior resistência ao cisalhamento da união que aquela recomendada pelo fabricante do RelyX ARC.

\section{ACKNOWLEDGEMENTS}

This investigation was supported by the São Paulo State Research Foundation (FAPESP - Grant \#07/06972-3).

\section{REFERENCES}

1. Attar N, Tam LE, McComb D. Mechanical and physical properties of contemporary dental luting agents. J Prosthet Dent 2003;89:127-134. 
2. Schneider R, de Goes MF, Henriques GEP, Chan DCN. Tensile bond strength of dual curing resin-based cements to commercially pure titanium. Dent Mater 2007;23:81-87.

3. Ozcan M, Pfeiffer P, Nergiz I. A brief history and current status of metal-and ceramic surface-conditioning concepts for resin bonding in dentistry. Quintessence Int 1998;29:713-724.

4. Tsuchimoto Y, Yoshida Y, Takeuchi M, Mine A, Yatani H, Tagawa $\mathrm{Y}$ et al. Effect of surface pre-treatment on durability of resin-based cements bonded to titanium. Dent Mater 2006;22:545-552.

5. Kern M, Thompson VP. Sandblasting and silica-coating of dental alloys: volume loss, morphology and changes in the surface composition. Dent Mater 1993;9:155-161.

6. Kern M, Thompson VP. Effects of sandblasting and silica-coating procedures on pure titanium. J Dent 1994;22:300-306.

7. Matinlinna JP, Vallittu PK. Silane based concepts on bonding resin composite to metals. J Contemp Dent Pract 2007;8:1-8.

8. Bertolotti RL. Adhesion to porcelain and metal. Dent Clin North Am 2007;51:433-51.

9. Cobb DS, Vargas MA, Fridrich TA, Bouschlicher MR. Metal surface treatment: characterization and effect on composite-to-metal bond strength. Oper Dent 2000;25:427-433.

10. Fawzy AS, El-Askary FS. Effect acidic and alkaline/heat treatments on the bond strength of different luting cements to commercially pure titanium. J Dent. 2009;37:255-263.

11. Taira Y, Matsumura H, Yoshida K, Tanaka T, Atsuta M. Adhesive bonding of titanium with a methacrylate-phosphate primer and self-curing adhesive resins. J Oral Rehabil 1995;22:409-412.

12. Yoshida K, Taira Y, Matsumura H, Atsuta M. Effect of adhesive metal primers on bonding a prosthetic composite resin to metals.
J Prosthet Dent 1993;69:357-362.

13. Matinlinna JP, Lassila LVJ, Vallittu PK. The effect of five silane coupling agents on the bond strength of a luting cement to a silicacoated titanium. Dent Mater 2007;23:1173-1180.

14. Santos JG, Fonseca RG, Adabo GL, Cruz CAS. Shear bond strength of metal-ceramic repair systems. J Prosthet Dent 2006;96:165-173.

15. Mukai M, Fukui H, Hasegawa J. Relationship between sandblasting and composite resin-alloy bond strength by a silica coating. J Prosthet Dent 1995;74:151-155.

16. Petridis H, Garefis P, Hirayama H, Kafantaris NM, Koidis PT. Bonding indirect resin composites to metal: part 2. Effect of alloy surface treatment on elemental composition of alloy and bond strength. Int J Prosthodont 2004; 17:77-82.

17. Sarafianou A, Seimenis I, Papadopoulos T. Effectiveness of different adhesive primers on the bond strength between an indirect composite resin and a base metal alloy. J Prosthet Dent 2008;99:377-387.

18. Papadopoulos T, Tsetsekou A, Eliades G. Effect of aluminium oxide sandblasting on cast commercially pure titanium surfaces. Eur J Prosthodont Rest Dent 1999;7:15-21.

19. Watanabe I, Kurtz KS, Kabcenell JL, Okabe T. Effect of sandblasting and silicoating on bond strength of polymer-glass composite to cast titanium. J Prosthet Dent 1999;82:462-467.

20. Mair L, Padipatvuthikul P. Variables related to materials and preparing for bond strength testing irrespective of the test protocol. Dent Mater 2010;26:e17-e23. 